International Journal of Advanced Chemistry, 2(2)(2014) 59-61
International Journal of Advanced Chemistry
Journal home page: $\begin{gathered}\text { www.sciencepubco.com/index.php/IJAC } \\ \text { doi: } 10.14419 / \text { ijac.v2i2.1981 } \\ \text { Research Paper }\end{gathered}$

\title{
In vitro antioxidant, antimicrobial and phytochemical properties of wild banana [Ensete gilletii (E. A. J. DE Wildman)] seeds extract
}

\author{
Afolayan Michael ${ }^{1 *}$, Salisu Abubakar ${ }^{2}$, Adebiyi Adedayo ${ }^{1}$, Idowu Doyinsola ${ }^{1}$, Fagbohun Adebisi ${ }^{1}$ \\ ${ }^{1}$ Chemistry Advanced Laboratory, Sheda Science \& Technology Complex, PMB 186 Garki-Abuja, Nigeria \\ ${ }^{2}$ Biotechnology Advanced Laboratory, Sheda Science \& Technology Complex, PMB 186 Garki-Abuja, Nigeria \\ *Corresponding author E-mail: afolayanmic@yahoo.com
}

\begin{abstract}
The proximate composition and phytochemical contents of wild banana seeds was examined. The seeds were also powdered and extracted with hexane, ethyl acetate and ethanol and each extract tested for its antimicrobial, antioxidant and phytochemical properties. The proximate analysis of the raw seeds showed that it contained carbohydrates $-68.41 \%$, proteins $-11.16 \%$, crude fibre $-1.1 \%$, lipids $6.27 \%$, ash $-3.20 \%$ and moisture $-9.86 \%$ while its phytochemical investigation revealed the presence of carbohydrates, terpenoids, saponins, alkaloids, sterols and tannins. The antimicrobial screening was done using disc diffusion method with disc potency of $60 \mu \mathrm{g} / \mathrm{disc}, 30 \mu \mathrm{g} / \mathrm{disc}$ and $15 \mu \mathrm{g} / \mathrm{disc}$ respectively and two groups of test organisms (bacteria and fungi) were used. The ethyl acetate and ethanolic extract were found to be effective on both groups of test organisms while the hexane extract did not show any activity on all the test organisms used. Concentrations of the plant extracts required for 50\% inhibition of DPPH radical scavenging effect (IC50) were recorded as $8.67,0.64,0.31$ and $0.14 \mathrm{mg} / \mathrm{ml}$ for the hexane fraction, ethyl acetate fraction, ethanol fraction and vitamin $\mathrm{C}$ respectively.
\end{abstract}

Keywords: Antimicrobial, antioxidant, Ensete gilletii, phytochemical, proximate.

\section{Introduction}

For the past two decades, there has been an increasing interest in the investigation of different extracts obtained from traditional medicinal plants as potential sources of new antimicrobial agents (Bonja \& Farrokhi 2004). Medicinal plants represent rich sources from which antimicrobial agents may be obtained. Plants are used medicinally in different countries and are sources of many potent and powerful drugs. Medicinal plants have been used for centuries before the advent of orthodox medicine. Leaves, flowers steams, roots, seeds, fruit and bark can all be constituents of herbal medicines. The medicinal values of these plants lie in their component phytochemicals which produce definite physiological actions on the human body. The active principles of many drugs found in plants are secondary metabolites. Therefore, basic phytochemical investigation of its extracts for major phytoconstituents is also vital.

Ensete is a genus of monocarpic flowering plants native to tropical regions of Africa and Asia. It is one of the three genera in the banana family, Musaceae (Baker \& Simmonds 1953). Wild banana (Ensete gilletii) is of the African specie. It is a wild 'banana'; a large monocarpic herb with unbranched pseudostem of concentric layers of fleshy leaf-petioles arising to $5 \mathrm{~m}$ high from a swollen base, not suckering like Musa spp., and dying after flowering. The seeds are widely used for household, domestic and personal uses (Burkill 1995).

In the present study, the hexane, ethyl acetate and ethanolic extracts of E. gilletii were screened for phytochemical constituents, antioxidant activity, antibacterial activity against Staphylococcus aureus, Escherichia coli, Klebsiella pneumonia and anti fungal activity against Candida albicans, Candida glabrata, Candida krusen.

\section{Experimental}

\subsection{Sample collection and preparation}

The fruits of Ensete gilletii (wild banana) were collected in Gwagwalada, FCT, Nigeria. The fruits were then cut open and the seeds carefully removed from the pulp, washed and air dried, after which it was pulverized to powder form with mortar and pestle. The powdered seeds were then kept in airtight container until required for further laboratory analysis.

\subsection{Extraction process}

Air dried and powdered seed samples, $500 \mathrm{~g}$ was successively extracted with n-hexane, ethyl acetate and ethanol in a soxhlet apparatus using $1000 \mathrm{ml}$ of each solvent. After the extraction, the extracts were concentrated using a rotary evaporator and the three extracts were kept in a refrigerator for further analysis.

\subsection{Proximate analysis}

Moisture, fat, crude fibre, protein, ash and carbohydrate contents were determined according to AOAC (2000) method.

\subsection{Phytochemical screening}

Phytochemical screening was carried out on the hexane, ethyl acetate and ethanolic extracts for the qualitative determination of 
major constituents using methods previously described (Harborne 1973, Trease \& Evans 1989, Sofowora 1993).

\subsection{Determination of antioxidant activity}

The radical scavenging activities of the plant extracts against DPPH (Sigma-Aldrich) were determined by UV-Visible Spectrophotometer at $517 \mathrm{~nm}$. Radical scavenging activity was measured by a slightly modified method previously described (Ayoola et al. 2008, Brand Williams et al. 1995). The following concentrations of the extracts were prepared, 0.05, 0.1, 0.5, 1.0, 2.0 , and $5.0 \mathrm{mg} / \mathrm{ml}$ in methanol (Analar grade). Vitamin $\mathrm{C}$ (Ascorbic acid) was used as the antioxidant standard at concentrations of $0.05,0.1,0.5,1.0,2.0$, and $5.0 \mathrm{mg} / \mathrm{ml} .1 \mathrm{ml}$ of the extract was placed in a test tube and $3 \mathrm{ml}$ of methanol was added, followed by $0.5 \mathrm{ml}$ of $1 \mathrm{mM}$ DPPH in methanol and thereafter the decrease in absorption was measured on a UVVisible Spectrophotometer 10 minutes later. A blank / control solution was prepared containing the same amount of methanol and DPPH. The actual decrease in absorption was measured against that of the control and the percentage inhibition was calculated. All test and analysis were run in duplicates and the results obtained were averaged. The radical scavenging activity (RSA) was calculated as the percentage inhibition of DPPH discolouration using the equation below:

$\%$ inhibition $=\{[\mathrm{Ab}-\mathrm{Aa}] / \mathrm{Ab}\} \times 100$

Where $\mathrm{Ab}$ is the absorption of the blank sample (without the extract) and Aa is the absorption of the extract.

\subsection{Antimicrobial screening}

All the Media were purchased from Sigma-Aldrich and were prepared in accordance with manufacturer instructions. The bacterial isolates were collected from Microbiology department of Bayero University Kano, Kano state, Nigeria on a slant Nutrient agar. The isolates were restored on Nutrient broth and confirmed using standard biochemical tests procedure (Cheesbrough 2002). While the collected fungal isolates were identified using fungichrome test kits in Nasarawa Specialist Hospital Kano, Kano state, Nigeria. The isolates were collected on a Potato dextrose agar slant and restored in Potato dextrose broth. Agar disc diffusion method as modified and adopted from [EUCAST 2012] was employed. The freshly prepared Mueller-Hinton agar and Potato dextrose agar plates were dried in a dryer for about 15 minutes to remove surface moisture. The plates were aseptically inoculated uniformly with test organism by streaking methods. With the aid of a sterile forcep, impregnated paper discs (Whatman No.1filter paper) containing the extract at different concentrations $(60,30$ and $15 \mu \mathrm{g} / \mathrm{disc})$ were arranged in three directions and pressed firmly onto the inoculated agar surface to ensure even contact including positive control at the center of the plate and negative control on the other side. Each disc was sufficiently spaced out and kept at least $15 \mathrm{~mm}$ from the edge of the plate and $25 \mathrm{~mm}$ from disc to disc to prevent overlapping of zones (Lawal et al. 2011). The plates are incubated at $37 \pm 2^{\circ} \mathrm{C}$ for $24 \mathrm{hrs}$. The zone diameters of the semi-confluent growths were measured with the aid of a meter rule to the nearest millimeter.

\section{Results and discussion}

The results of the proximate analysis, phytochemical screening, antioxidant activity and antimicrobial screening are presented in tables $1-5$ below:

Table 1: Proximate composition of wild banana seeds

\begin{tabular}{ll}
\hline Constituents & \% Composition \\
\hline Moisture & 9.86 \\
Ash & 3.20 \\
Fat & 6.27 \\
Crude fibre & 1.10 \\
Protein & 11.16 \\
Carbohydrate & 68.41 \\
\hline
\end{tabular}

Table 2: Phytochemical screening result of wild banana extracts.

\begin{tabular}{llll}
\hline Test & Hexane & Ethyl acetate & Ethanol \\
\hline Carbohydrate & - & - & - \\
Alkaloids & - & - & + \\
Tannins & - & - & + \\
Glycosides & - & - & - \\
Saponins & - & - & - \\
Steroids & - & - & + \\
Flavonoids & + & - & - \\
Resins & - & - & - \\
Phenols & - & + & + \\
Balsam & - & + & - \\
Volatile oils & - & - & - \\
Phlobatanins & - & + & + \\
Cardiac glycosides & - & - & - \\
Terpenoids & - & - & - \\
\hline
\end{tabular}

Table 3: \% Inhibition of wild banana extracts at different concentrations compared with Vitamin C.

\begin{tabular}{lllllll} 
extract & $\begin{array}{l}0.05 \\
\mathrm{mg} / \mathrm{ml}\end{array}$ & $\begin{array}{l}0.1 \\
\mathrm{mg} / \mathrm{ml}\end{array}$ & $\begin{array}{l}0.5 \\
\mathrm{mg} / \mathrm{ml}\end{array}$ & $\begin{array}{l}1 \\
\mathrm{mg} / \mathrm{ml}\end{array}$ & $\begin{array}{l}2 \\
\mathrm{mg} / \mathrm{ml}\end{array}$ & $\begin{array}{l}5 \\
\mathrm{mg} / \mathrm{ml}\end{array}$ \\
\hline $\begin{array}{l}\text { Hexane } \\
\text { Ethyl }\end{array}$ & 1.40 & 3.12 & 3.68 & 6.17 & 11.53 & 10.33 \\
acetate & 27.30 & 56.49 & 69.06 & 77.70 & 50.80 & 17.29 \\
$\begin{array}{l}\text { Ethanol } \\
\text { Vit. C } \\
\text { (standard) }\end{array}$ & 65.21 & 72.66 & 79.38 & 72.68 & 63.05 & 25.78 \\
\hline
\end{tabular}

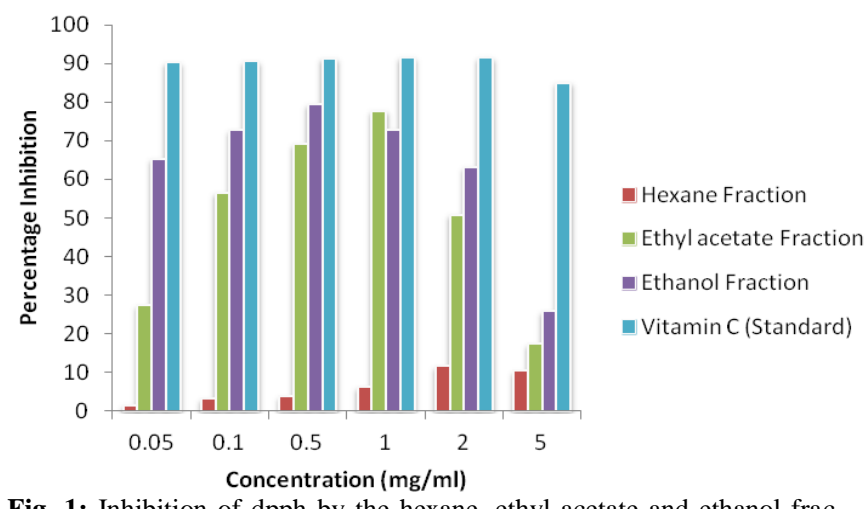

Fig. 1: Inhibition of dpph by the hexane, ethyl acetate and ethanol fractions.

Table 4: Ethyl acetate extract zone of inhibitions against test organisms.

\begin{tabular}{|c|c|c|c|c|c|}
\hline \multirow[t]{2}{*}{$\begin{array}{l}\text { Test Organ- } \\
\text { isms }\end{array}$} & \multicolumn{3}{|c|}{$\begin{array}{l}\text { Disc Po- } \\
\text { tency }(\mu \mathrm{g} / \mathrm{disc})\end{array}$} & \multirow[t]{2}{*}{$\begin{array}{l}\text { Positive Control } \\
\text { CLP/NST } \\
(60 \mu \mathrm{g} / \text { disc })\end{array}$} & \multirow[t]{2}{*}{$\begin{array}{l}\text { Negative } \\
\text { Control } \\
\text { (DMSO) }\end{array}$} \\
\hline & 15 & 30 & 60 & & \\
\hline \multicolumn{6}{|l|}{ Test bacteria } \\
\hline Staph. aureus & 7 & 9 & 11 & 22 & NA \\
\hline E. coli & 7 & 8 & 10 & 20 & NA \\
\hline $\begin{array}{l}\text { Kleb. pneu- } \\
\text { monia }\end{array}$ & 8 & 8 & 9 & 20 & NA \\
\hline Test fungi & & & & & \\
\hline C. albicans & NA & NA & 7 & 18 & NA \\
\hline C. glabrata & 7 & 8 & 8 & 20 & NA \\
\hline C. krusen & NA & 7 & 8 & 20 & NA \\
\hline
\end{tabular}

\subsection{Proximate analysis}

The result shown in Table 1 indicates proximate constituents: moisture $(9.86 \%)$, ash $(3.20 \%)$, crude fibre $(1.10 \%)$, protein $(11.16 \%)$, fat $(6.27 \%)$ and carbohydrate $(68.41 \%)$. The proximate analysis showed that wild banana seeds could serve as a good source of energy, dietary fibre, minerals and protein thus contributing to the palatability and supplementation of feed in animal nutrition due to its relatively high carbohydrate, fat, ash and protein content. 
Table 4: Ethyl acetate extract zone of inhibitions against test organisms

\begin{tabular}{llllll}
\hline $\begin{array}{l}\text { Test organ- } \\
\text { isms }\end{array}$ & \multicolumn{2}{l}{$\begin{array}{l}\text { Disc Po- } \\
\text { tency }(\mu \mathrm{g} / \mathrm{disc})\end{array}$} & $\begin{array}{l}\text { Positive Control } \\
\text { CLP/NST } \\
(60 \mu \mathrm{g} / \mathrm{disc})\end{array}$ & $\begin{array}{l}\text { Negative } \\
\text { Control } \\
\text { (DMSO) }\end{array}$ \\
\hline $\begin{array}{l}\text { Test bacteria } \\
\text { Staph. aureus }\end{array}$ & 9 & 10 & 12 & 22 & NA \\
$\begin{array}{l}\text { E. coli } \\
\text { Kleb. }\end{array}$ & 7 & 9 & 9 & 20 & NA \\
pneumonia & 8 & 10 & 10 & 20 & NA \\
Test fungi & & & & & \\
C. albicans & $\mathrm{NA}$ & 7 & 7 & 18 & NA \\
C. glabrata & 7 & 7 & 8 & 20 & NA \\
C. krusen & 7 & 7 & 8 & 20 & NA \\
\hline
\end{tabular}

Values are zone of inhibitions in (mm)

Legend: CLP - Chloramphenicol, NST - Nystatin, $\mu \mathrm{g}$ - Microgram, DMSO - Dimethylsulphoxide NA - No Activity

\subsection{Phytochemical screening}

Phytochemical screening of the hexane, ethyl acetate and ethanol extracts revealed the presence of more metabolites in the ethanol fraction than in the ethyl acetate and hexane fractions (Table 2), this may be as a result of the solubility of the plant extracts in ethanol than in ethyl acetate and hexane. The ethanol fraction contained alkaloids, tannins, steroids, phenols and phlobatanins. The ethyl acetate fraction contained phenols, balsams and phlobatanins while the hexane fraction only contained flavonoids. Carbohydrates, glycosides, saponins, resins, volatile oils, cardiac glycosides and terpenoids were not detected in any of the fractions. These chemical constituents present in the extracts have many therapeutic values which explain their antimicrobial and antioxidant properties. Tannins are plant metabolites well known for their antimicrobial properties (Tsechesche 1971). Flavonoids have both antifungal and antibacterial activity. They also possess anti-inflammatory properties (Iwu et al. 1999). Flavonoids and steroids are known to have antimicrobial and curative properties against several pathogens [Usman et al. 2007, Hassan et al. 2004]. The phenolic compounds are known to possess antioxidant properties [Gomez - Alonso et al. 2002].

\subsection{Antioxidant activity}

$\mathrm{IC}_{50}$ of $8.67,0.64,0.31$ and $0.14 \mathrm{mg} / \mathrm{ml}$ were recorded for the hexane fraction, ethyl acetate fraction, ethanol fraction and vitamin $\mathrm{C}$ respectively (Table 3 ). The ethanol fraction was the most potent of the three fractions having a maximum inhibition of $79.38 \%$ at $0.5 \mathrm{mg} / \mathrm{ml}$ but was however slightly less potent than the Vitamin $\mathrm{C}$ standard. The ethyl acetate fraction also demonstrated good free radical scavenging activity against DPPH having a maximum percentage inhibition of $77.70 \%$ at $1 \mathrm{mg} / \mathrm{ml}$. The hexane extract however demonstrated poor antioxidant activity with a maximum percentage inhibition of $11.53 \%$ at $2 \mathrm{mg} / \mathrm{ml}$. The antioxidant activity for all the fractions are dose related and increases as the concentration increases. Phenolic compounds in herbs act as antioxidants due to their redox properties, allowing them to act as reducing agents, hydrogen donors, free radical quenchers and metal chelators (Javanraedi 2003) this may be the reason why the ethanol and ethyl acetate fraction has higher percentage inhibition against DPPH. Tannins are also a major group of compounds that act as primary antioxidant or free radical scavengers (Polterait 1997) hence the higher potency of the ethanol fraction over the ethyl acetate fraction can be due to the presence of tannins in the ethanol fraction which is absent in the ethyl acetate fraction. Thus, the high antioxidant activity of the ethanol and ethyl acetate fraction can be attributed to the presence of phenols in both fractions and tannins in the ethanol fraction alone.

\subsection{Antimicrobial assay}

The antimicrobial assay of ethyl acetate extract result shown in Table 4 indicates that the extract is active against all the three tested bacterial isolates with high zone of inhibition on Staph aureus and E. coli at $60 \mu \mathrm{g} / \mathrm{disc}(11 \mathrm{~mm}$ and $10 \mathrm{~mm})$ respectively. For the test fungi, the ethyl acetate extract showed a slight zone of inhibition on $C$. albicans $(7 \mathrm{~mm})$ and $(8 \mathrm{~mm})$ in each of $C$. glabrata and $C$. krusen at $(60 \mu \mathrm{g})$ disc concentration. The ethanolic extract (Table 5) showed activity on all the bacterial test isolate with zone of inhibition on Staph. aureus $(12 \mathrm{~mm})$, E. coli $(9 \mathrm{~mm})$ and Kleb. pneumonia $(10 \mathrm{~mm})$ at $60 \mu \mathrm{g} / \mathrm{disc}$, while in the fungal test isolates, the extract showed the highest activity on $C$. glabrata and $C$. krusen $(8 \mathrm{~mm})$ each at the same disc concentration of 60 $\mu \mathrm{g} /$ disc. Even though the extracts were generally less active when compared with standard broad spectrum antibiotic (Chloramphenicol) with the minimum zone of inhibition diameter of $(20-$ $22 \mathrm{~mm}$ ) for test bacteria and antifungal (Nystatin) $(18-20 \mathrm{~mm})$ for test fungi at equal disc potency of $(60 \mu \mathrm{g} / \mathrm{disc})$. The difference in activity may be related to the fact that both the standard antibacterial and antifungal are at refined form, while the extract contains both the active and inactive substances. The hexane extract however, did not show any activity on all the test organisms used.

\section{Conclusion}

In the present study the phytochemical, antimicrobial and antioxidant activity of the hexane, ethyl acetate and ethanol extracts of wild banana seeds were evaluated. The results of the present study suggest that the ethyl acetate and ethanol fractions had potent antioxidant activity. The ethyl acetate and ethanol extracts also showed promising antibacterial and antifungal properties. More detailed studies would be needed to ascertain its potency and also characterise it.

\section{References}

[1] Bonja C; Farrokhi K. J. Antimicrob. Chemother., 2004, 3, 273.

[2] Baker RED; Simmonds N. W. Kew Bulletin, 1953, 8 (3) 405.

[3] Burkill HM; () The useful plants of West Africa $2^{\text {nd }}$ Ed. Royal Kew botanical Garden, Kew London, 1995, 144 - 150.

[4] AOAC. Official Methods of Analysis, 15th ed. Washington, DC: Association of Official Analytical Chemists, 2000.

[5] Harbone JB. Phytochemical Methods London. Chapman and Hall Ltd. 1973, 49-188.

[6] Trease GE; Evans WC. Pharmacognosy. 13th edn. Bailliere Tindall, London. 1989, 176-180.

[7] Sofowora A. Medicinal plants and Traditional Medicine in Africa. Spectrum Books, Ibadan. 1993, 150.

[8] Ayoola GA; Coker HAB; Adesegun SA; Adepoju - Bello AA; Obaweya K; Ezennia EC; Atangbayila TO. Tropical Journal of Pharmaceutical Research, 2008, 7 (3), 1019-1024.

[9] Brand-Williams W; Cuvelier MO; Berset C. Lebensmittelwissenchaft and technologie, 1995, 28, 25-50.

[10]Cheesbrough M; Cambridge University press, London. 2002, 2,76100.

[11]European Committee on Antimicrobial Susceptibility Testing (EUCAST) 2012, Version 2.1.

[12]Lawal D; Mukhtar MD; Taura DW. () A preliminary study of synergistic action of Dodonea Viscosa Linn leaf and Anona comosus (Linn) MERR. Peel extracts on Aeromonas hhdrophila and Salmonella species. 2011.

[13] Tsechesche R; Pharmacognosy and phytochemistry proceeding of the 1st international congress. Verlong, Berlin, Heidelberg, New York. 1971, $274-276$

[14]Iwu MM; Angela RD; Chris O. ASHS press Mexandrria 1999457 462.

[15]Usman H; Abdulrahman FK; Ladan AA. Res. J. Biosc. Medwell J. 2007, 2 (3) 244-247.

[16]Hassan MA; Oyewale AO; Amupitan JO; Abdullahi MS; Okonwo EM; J. chem. Sci. Nigeria 2004, 29, 36-49.

[17]Gomez - Alonso S; Salvador M; Fragapan G. Journal of Agriculture and Food Chemistry, 2002, 50, 6812-6817.

[18] Javanraedi J; Stushnoff C; Locke E; Vivanco, JM. Food Chem. 2003 , 83, 547-550.

[19]Polterait O. Current Org.Chem., 1997, 1, 415-440. 